\title{
Zastosowanie drewna klejonego w konstrukcji budynków wysokościowych, na przykładzie realizacji z krajów zachodnich
}

\author{
Michał Dmitruk \\ https://orcid.org/0000-0002-6368-4206 \\ m.dmitruk@pollub.pl
}

Katedra Architektury, Urbanistyki i Planowania Przestrzennego,

Wydziat Budownictwa i Architektury, Politechnika Lubelska

\begin{abstract}
Streszczenie: Z architekturą nowoczesnych, wysokich i wysokościowych budynków z XX i początków XXI wieku kojarzone są przede wszystkim takie materiały jak stal, szkło i beton. Wraz z rozwojem technologii, coraz popularniejsze w krajach zachodnich staje się stosowanie materiałów pochodzenia roślinnego, takich jak drewno klejone. Wykorzystanie drewna jako materiału konstrukcyjnego przynosi wiele korzyści zarówno ekonomicznych, technologicznych jak i użytkowych. Jest to budulec bardziej elastyczny, lżejszy i często wytrzymalszy niż konstrukcje powszechnie stosowane. Dzięki technologii klejenia krzyżowego lub warstwowego, budynki są w stanie uzyskać znaczne wysokości, przy zachowaniu odpowiednich parametrów wytrzymałościowych. Materiał ten okazuje się być łatwiejszy w transporcie, a przy odpowiednim przygotowaniu prefabrykowanych elementów, również przyspiesza procesy budowlane, ułatwiając montaż. Jest to również materiał ekologiczny. Przy odpowiednio zaplanowanej gospodarce leśnej, jest w stanie zapewnić zrównoważone zużycie budulca, jednocześnie minimalizując koszt dla środowiska naturalnego, m.in. obniżając emisję $\mathrm{CO}_{2}$. Główną przeszkodą w zastosowaniu wspomnianej technologii na szerszą skalę, są liczne obostrzenia prawne, dotyczące wytrzymałości i odporności ogniowej. Przytaczane w poniższym artykule badania oraz przykłady realizacji, pokazują jednak iż drewno klejone jest w stanie zachować odpowiednie parametry, zapewniając trwałość konstrukcji i bezpieczeństwo użytkownikom obiektu.
\end{abstract}

Słowa kluczowe: architektura, budynki wysokościowe, drewno klejone, bezpieczeństwo pożarowe

\section{Wprowadzenie}

Używanie drewna, jako materiału budowlanego ma swoją wielowiekową tradycję w wielu regionach świata, wynikającą z łatwości obróbki, znacznej wytrzymałości i szerokiej dostępności. Wysokie i wysokościowe drewniane konstrukcje, takie jak na przykład mierząca 67,3 m pagoda świątyni Fogong ${ }^{1}$ w Chinach powstawały już wiele wieków wcześniej. Materiał ten był szeroko stosowany również w tradycyjnej architekturze krajów Azjatyckich, Europejskich (Pn.) i Ameryki Północnej. XX-to wieczny intensywny rozwój miast oraz pojawienie się konstrukcji żelbetowych, uważanych jako trwalsze, bezpieczniejsze i bardziej przewidywalne ${ }^{2}$, spowodował wyraźne odejście od stosowania drewna jako elementu dominującego w konstrukcji budynków. Od kilku lat obserwować można jednak powrót materiałów naturalnych używanych w budownictwie. Drewno poddane odpowiedniej obróbce jest w stanie funkcjonować jako zupełnie nowy rodzaj budulca, pozbawiony wad typowych dla suro- 
wego materiału. O opracowaniu i stosowaniu drewna laminowanego krzyżowo pierwsze publikacje naukowe wspominają już w latach 90` XX wieku. Również w tym okresie materiał uzyskał pierwsze atesty w Niemczech i Austrii. Podstawową zaletą nowego materiału na bazie drewna była możliwość przygotowania elementów o znacznych parametrach wielkościowych, umożliwiając jednocześnie wykonywanie konstrukcji o pokaźnej rozpiętości. Nowy, wysoko przetworzony budulec charakteryzował się dużą wytrzymałością i znaczną odpornością na warunki zewnętrzne (w tym narażenie na ogień czy odporność na korozję biologiczną). Pierwotnie, w omawianej technologii realizowano jedynie niewielkie obiekty budowlane. W kolejnych latach zaczęto jednak wykorzystywać drewno klejone jako element konstrukcyjny hal sportowych i widowiskowych, zapewniający dużą rozpiętość przekryć dachowych. Ze względu na liczne obostrzenia prawne, związane z wymogami bezpieczeństwa, dopiero w ostatniej dekadzie zaczął postępować rozwój budynków wysokich i wysokościowych o konstrukcji drewnianej. Technologia stopniowo zyskuje coraz większą popularność w krajach Europy Północno-Zachodniej, gdzie występuje dostatek naturalnego surowca, jednocześnie istnieją wyspecjalizowane zakłady produkcyjne, zajmujące się wytwarzaniem drewna klejonego. Równie ważnym czynnikiem jest powszechnie panująca inicjatywa związana z implementacją rozwiązań proekologicznych w budownictwie. Razem ze wzrostem popularności materiału, zwrócono uwagę na liczne zalety z nim związane (lekkość, wytrzymałość, odporność na czynniki destruktywne oraz łatwość w transporcie, montażu i obróbce), co w znacznym stopniu wpływa na wyraźny wzrost produkcji i szerokie zapotrzebowanie na rynku budowlanym. ${ }^{3}$

Wykres poniżej przedstawia dynamiczny wzrost produkcji, związanej z rosnącym zapotrzebowaniem na $\mathrm{CLT}^{4}$ na przestrzeni ostatnich trzech dekad.

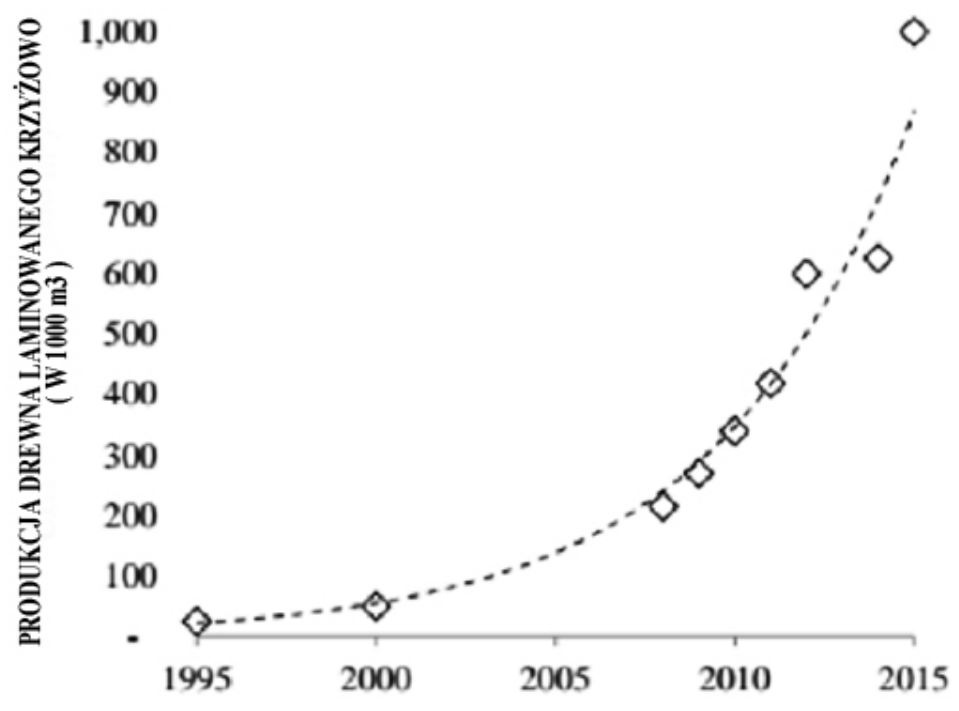

Ryc. 1. Światowa produkcja elementów z drewna laminowanego $\mathrm{w}^{3}{ }^{3}$, na przestrzeni lat.

Źródło: Sherifi E, Fager-Thompson M., Mass timber in tall buildings design A Major Qualifying Project Report, Faculty of Worcester Polytehnic Institute's Civil and Enviromental Engineering Department, 2017

Obecnie na terenie Europy znajduje się ponad 100 budynków wysokich i wysokościowych, zrealizowanych we wspomnianej technologii. ${ }^{5}$

Wykorzystanie drewna w konstrukcji budynków wysokich, poza walorami estetycznymi i technicznymi staje się przedmiotem zainteresowania, ze względu na fakt iż jest to surowiec odnawialny, w przeciwieństwie do stosowanych powszechnie betonu i stali. Oznacza to, że zarówno negatywny wpływ środowiskowy budynku wykonanego w omawianej technologii jest znacznie mniejszy, nie wykorzystując nieodnawialnych zasobów naturalnych, oraz to, że zastosowany surowiec budowlany nadaje się do ponownego wykorzystania po rozbiórce budynku. 


\section{Współcześnie realizowane budynki}

Impulsem do powstawania wysokich drewnianych budynków był zrealizowany w 2008 roku w Londynie budynek mieszkalny Stadthaus. Dziewięciopiętrowy obiekt, zaprojektowany przez pracownię Waugh Thistleton, we współpracy z biurem konstrukcyjnym Techiker i firmą $\mathrm{KLH}$, produkującą drewniane panele, był w chwili powstania drugim najwyższym drewnianym obiektem użytkowym na świecie ${ }^{6}$. Jest to pierwszy budynek tej wysokości (29 m) na świecie, zrealizowany w pełni z elementów drewnianych. Dotyczy to nie tylko konstrukcji obiektu, ale również schodów, stropów, ścian działowych oraz szybów dźwigów osobowych. Realizacja udowodniła, że tego typu konstrukcja jest zarówno uzasadniona ekonomicznie oraz jest w stanie spełnić normy zapewniające bezpieczeństwo mieszkańcom.
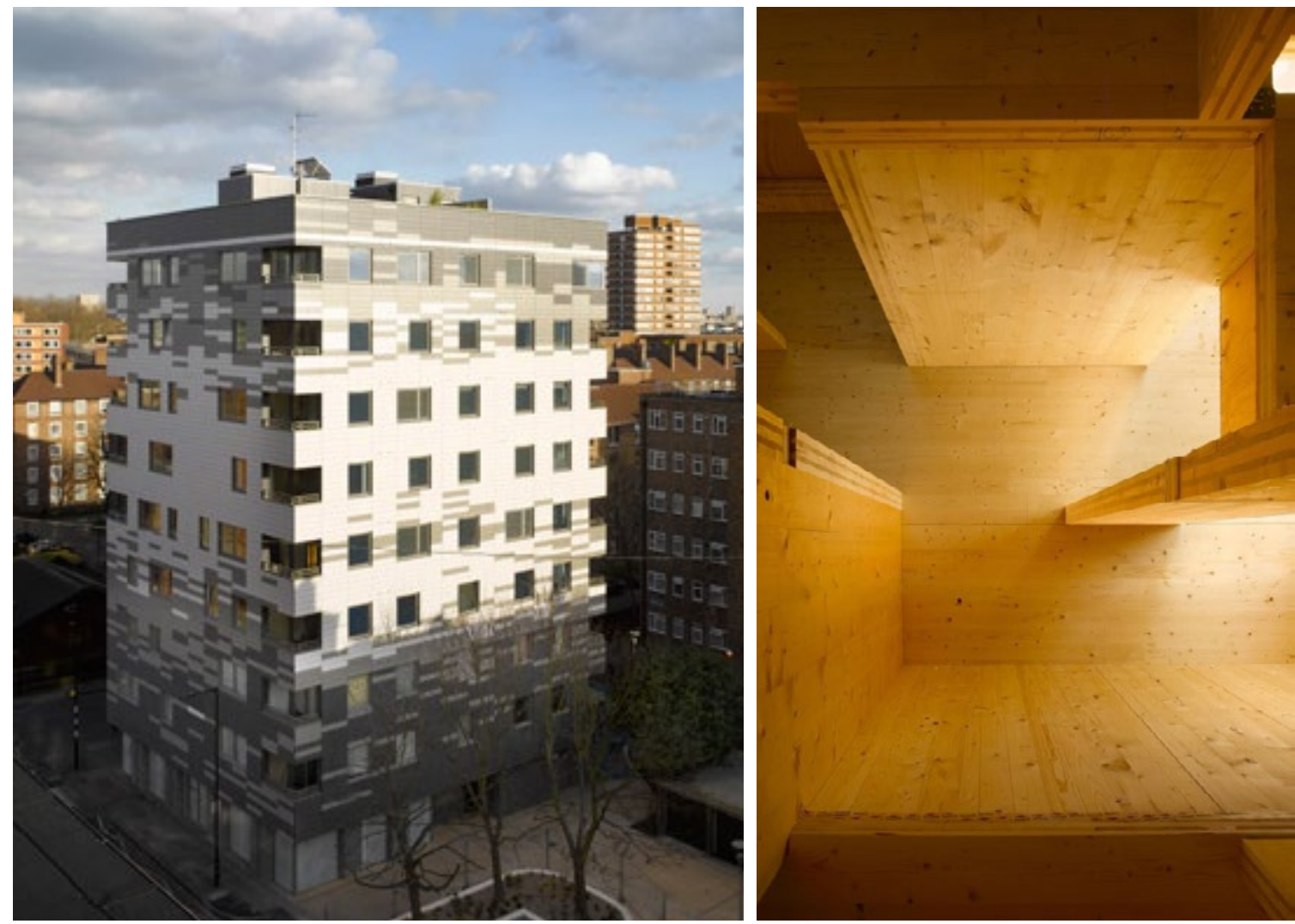

Ryc. 2. Budynek Stadthaus z zewnątrz i wewnątrz, 24 Murray Grove, Hoxton, Londyn

Źródło: Strona pracowni architektonicznej Waugh Thistleton, http://waughthistleton.com/murray-grove/ - licencja otwarta, stan na dzień 20.03.2020.

W roku 2015 miano najwyższego, drewnianego budynku uzyskał Treet (norw. drzewo), zbudowany w Bergen w Norwegii. Budynek posiada 14 kondygnacji i mierzy 49 metrów wysokości. Cechą charakterystyczną obiektu, jest konstrukcja, wykonana z drewnianych modułów ramowych, o wielkości poszczególnych mieszkań. Elementy konstrukcyjne (belki słupy i stężenia) wykonane są z drewna klejonego. Co pięć kondygnacji zaprojektowano betonową warstwę dociskową, w celu zwiększenia ciężaru budynku i zarazem odporności na kołysanie podczas silniejszego wiatru ${ }^{7}$. Zewnętrzna elewacja składa się ze szkła i stali. Projektanci ${ }^{8}$ podjęli liczne starania w celu

7 Za: Abrahamsen R.B., Malo K.A, Structural design and assembly of Treet-a 14-storey timber residental building in Norway, [w:] materiały pokonferencyjne World Conference on Timber Engineering, 10.08.2014 r.

8 Biuro Artec AS 
zapewnienia odpowiedniej izolacyjności termicznej przegród, dzięki czemu budynek spełnia nie tylko norweskie normy cieplne, jak i również wykonany jest w standardzie domu pasywnego. Częściowo prefabrykowane moduły zostały wykonane w zakładach produkcyjnych na terenie Estonii, następnie dostarczone i finalnie zmontowane w Bergen.
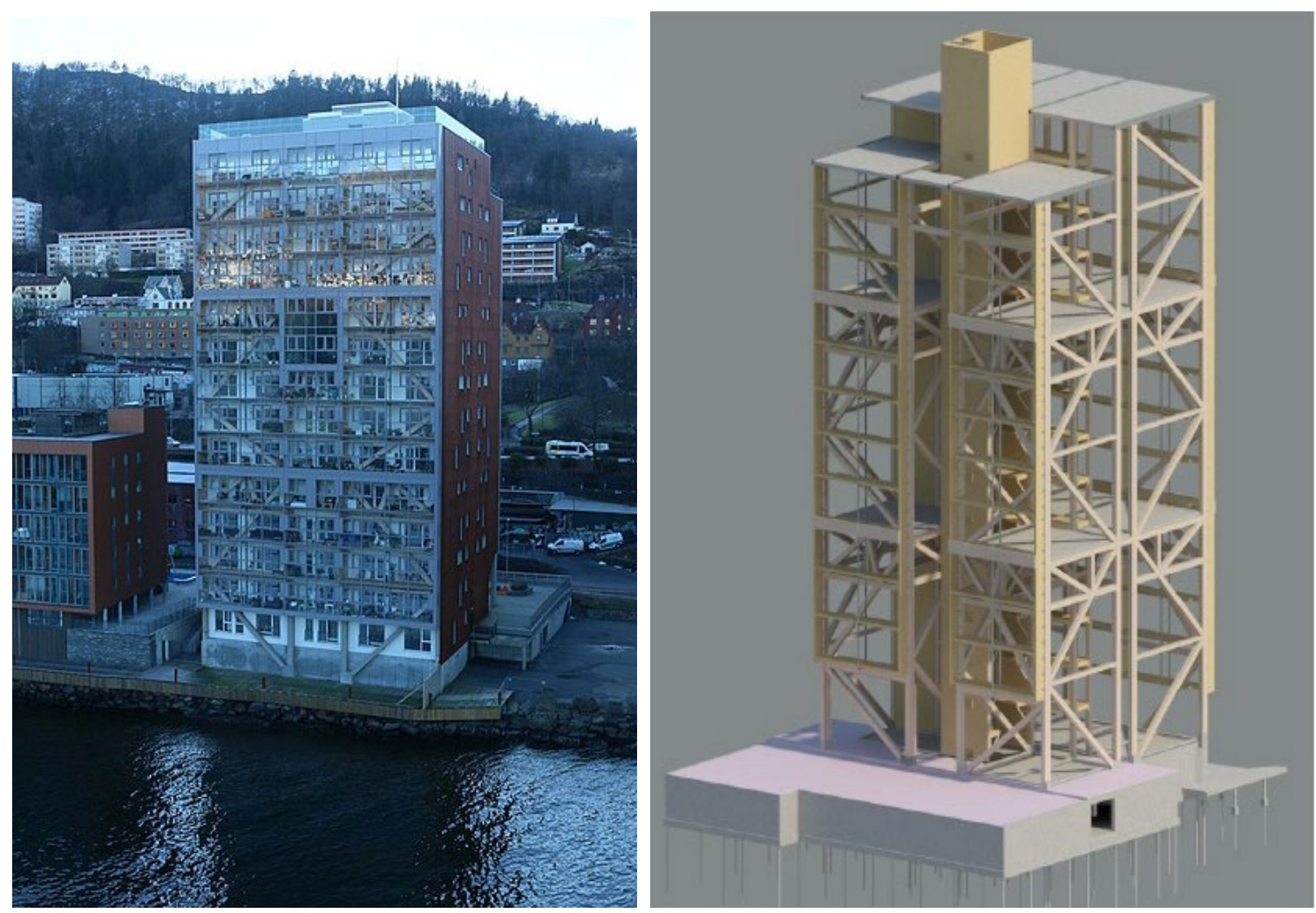

Ryc. 3. Widok na budynek Trett w Bergen, oraz jego schemat konstrukcyjny

Źródło: Wikipedia.pl https://commons.wikimedia.org/wiki/File:Treet_(Bergen)_011.jpg licencja otwarta, stan na dzień 20.03.2020.

Tendencja do realizacji coraz wyższych obiektów o konstrukcji drewnianej, zapoczątkowana w 2008 roku, nadal się utrzymuje. Wraz z rozwojem technologii drewna laminowanego krzyżowo i lepszym poznaniem jego parametrów technicznych, zaczęły sie pojawiać kolejne obiekty, bijące rekordy wysokości. W 2016 roku tytuł najwyższego budynku wykonanego w technologii drewnianej posiadał 18-kondygnacyjny, 55 metrowy akademik Brock Commons Tallwood House zlokalizowany w Vancouver w Kanadzie. Projekt budynku powstał dzięki współpracy kilku biur projektowych (Acton Ostry Architects Inc oraz Fast + Epp) a także firm zajmujących się produkcją elementów drewnianych, laminowanych (Structurlam). Obiekt posiada hybrydowy układ konstrukcyjny, składający się z drewnianych ram, wzmocnionych stalowymi elementami, wspartych na dwóch żelbetowych rdzeniach. Dzięki precyzyjnemu wykonaniu elementów prefabrykowanych, montaż na placu budowy całego, 18-sto kondygnacyjnego obiektu trwał jedynie 70 dni, co stanowi niezwykle krótki czas, w porównaniu do powszechnie stosowanych technologii budowlanych. Sam proces budowy porównywano do tworzenia obiektu z klocków lego. ${ }^{9}$ 

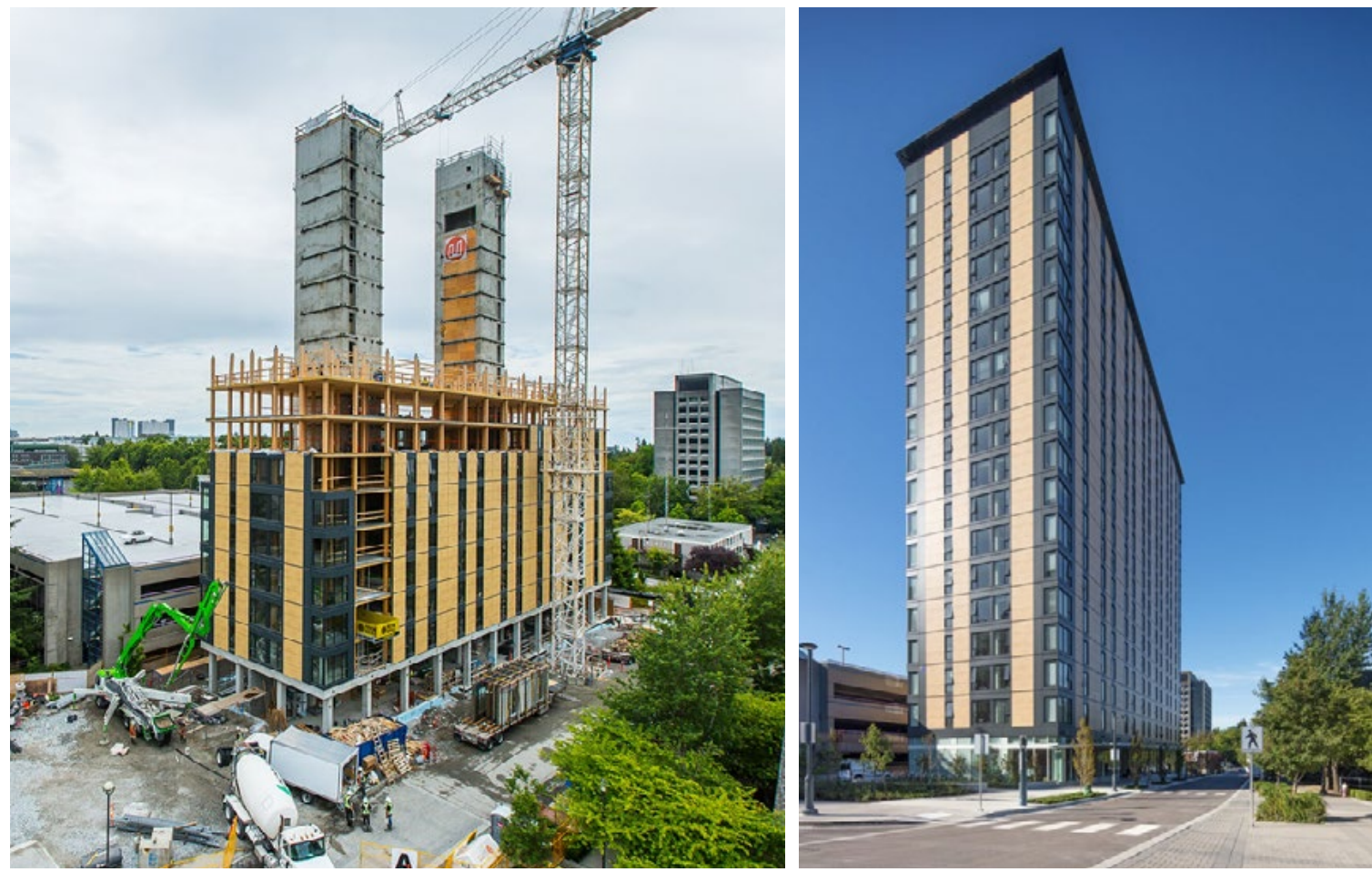

Ryc. 4. Widok na budynek Brock Commons Tallwood House w Vancouver, w czasie realizacji i po zrealizowaniu Źródło: https://www.flickr.com/ licencja otwarta, stan na dzień 20.03.2020.
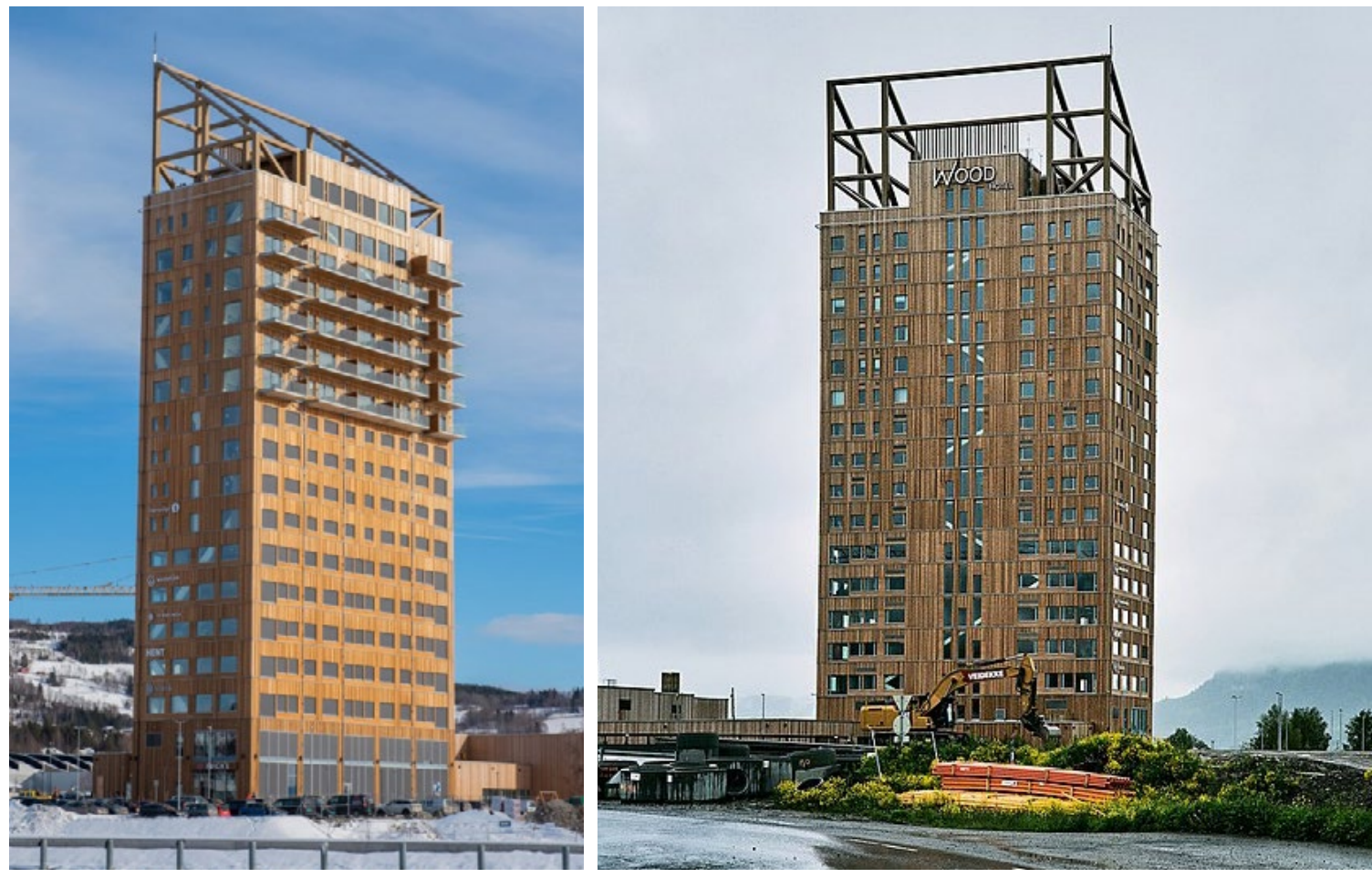

Ryc. 5. Widok na budynek Mjøstårnet Brumunddal

Źródło: Wikipedia.pl https://pl.m.wikipedia.org/wiki/Plik:Narsot\%C3\%A5rnet_IV.jpg licencja otwarta, stan na dzień 20.03.2020. 
Obecnie najwyższym budynkiem na świecie, w którego konstrukcji zastosowano drewno klejone jest Mjøstårnet ${ }^{10}$ - wielofunkcyjny, 18 kondygnacyjny obiekt, znajdujący się w Brumunddal, w Norwegii. Budynek zaprojektowany przez norweskie biuro Voll Arkitekter ma 85,4 metra wysokości. Posiada część hotelową, biurowo-konferencyjną, a także basen i restaurację. Do budowy obiektu użyto zarówno drewna klejonego w technologii glulam (GLT), jak i klejonego krzyżowo (CLT). Materiał dostarczono z zakładów produkujących go lokalnie. Elementami konstrukcyjnymi budynku, niewykonanymi z drewna, a z betonu są stropy od 11 kondygnacji wzwyż. Wynika to z potrzeby dociążenia budynku, w celu uniknięcia ruchów spowodowanych naporem wiatru, a co za tym idzie dyskomfortu użytkowników. Elewacje, oraz elementy wewnętrzne obiektu, takie jak ściany działowe, schody, szyby dźwigów osobowych a nawet meble i wyposażenie, również zostały wykonane z drewna klejonego. Projekt budynku otrzymał dwie prestiżowe nagrody: Norwegian Tech Award i New York Design Awards

\section{Technologia wykonania}

Technologia produkcji drewna klejonego opracowana została w Austrii w latach 90 XX wieku, a następnie rozwijana była w Niemczech oraz we Włoszech, głownie, jako produkt pomagający zminimalizować ilość odpadów drzewnych. Technologia obecnie znajduje zastosowanie również w krajach Europy Północnej, jak i w Kanadzie. Obecnie wykorzystywane są rozmaite techniki zespajania drewnianych fragmentów, w celu wytworzenia elementu o jednolitych właściwościach. Są to:

a drewno klejone krzyżowo (Cross Laminated Timber - CLT) składające się z kilku warstw paneli (zwykle od 3 do 7), ułożonych do siebie pod kątem, a następnie sklejonych;

nail-lam (Nail-Laminated Timber - NLT) - panele drewniane łączone są ze sobą przy pomocy gwoździ lub wkrętów, w celu uzyskania jednolitego elementu;

- glulam (Glued-Laminated Timber - GLT), panele drewniane ułożone warstwowo, wzdłuż włókien, następnie sklejone i zabezpieczone wytrzymałym, wodoodpornym spoiwem;

- płyta wiórowa ( Structural composite lumber - SCL), jednolity element wykonany poprzez sprasowanie i sklejenie wytrzymałym wodoodpornym spoiwem ścinków drewnianych.

Wszystkie powyższe technologie mają swoje zastosowanie w budowie elementów przytoczonych powyżej drewnianych budynków wysokościowych, z czego ze względu na właściwości wytrzymałościowe, CLT i GLT ma najszersze zastosowanie w ich konstrukcji. Klejenie krzyżowe drewna pozwala uzyskać właściwości mechaniczne które mogą konkurować z innymi technologiami stosowanymi szeroko w budownictwie. Wysoka wytrzymałość i sztywność elementów z CLT porównywalna jest do stali i znacznie lepsza niż elementów betonowych. Wynika to z przeprowadzanego procesu homogenizacji, podczas którego naturalna zmienność struktury i właściwości drewna naturalnego (nieobrobionego) zostaje wyeliminowana. Cały proces odbywa się mechanicznie i jest w pełni zautomatyzowany, dostarczając w efekcie gotowy do użycia surowiec budowlany. W przygotowaniu elementów z CLT bardzo pomocne okazuje się planowanie projektu w 3D (wykorzystując technologię BIM), jak i również wykorzystanie wysokoprecyzyjnych maszyn tnących CNC, które są w stanie wyprodukować element gotowy do złożenia na placu budowy. Niewielka kurczliwość elementów z drewna klejonego również pomaga w rozwoju technologii prefabrykacji i przyspieszeniu procesów budowlanych in situ. Właściwością konstrukcji drewnianych jest również mniejsza masa własna materiału, niż jego odpowiedniki w stosowanych powszechnie technologiach budowlanych. ${ }^{11} Z$ jednej strony ułatwia to znacznie transport i montaż elementów, jednocześnie stwarza dodatkowe wyzwania w kwestii sił wyporu gruntu, bądź narażenia na siły naporu wiatru oraz wstrząsy sejsmiczne. Niższa sztywność na łączeniach elementów oraz mniejsza masa własna materiału, w przypadku omawianych w niniejszym artykule budynków wysokich i wysokościowych, może powodować wyraźny ruch w wyżej położonych kondygnacjach budynku, co przekłada się na dyskomfort jego użytkowników. Zjawisko może pojawiać się nawet w przypadku bardzo niewielkich ruchów na łączeniach elementów. W celu eliminacji

10 Rekord potwierdzony przez Council on Tall Buildings and Urban Habitat - międzynarodową organizację, której celem jest szerzenie wiedzy na temat wysokich budynków.

11 Masa budynków wykonanych głownie z betonu zbrojonego wynosi zwykle ok. $300 \mathrm{~kg} / \mathrm{m}^{3}$, obiektów stalowych, z betonowym rdzeniem i stropami ok. $160 \mathrm{~kg} / \mathrm{m}^{3}$ a na przykład wykonany z drewna klejonego Oakwood Tower ma masę jedynie $125 \mathrm{~kg} / \mathrm{m}^{3}$. 
wspomnianego efektu bardzo ważne jest precyzyjne przygotowanie elementów prefabrykowanych konstrukcji drewnianej, jak i również ich umiejętny montaż na budowie. Problemy te, jak wskazano w opisie przytaczanych powyżej przykładów, rozwiązano za pomocą betonowych płyt dociskowych, stosowanych co kilka kondygnacji, zwiększających masę własną obiektu. ${ }^{12}$ Istotna jest również kwestia smukłości budynku, gdzie należy stosować kompromis, pomiędzy stosunkowo niewielką powierzchnią strony dowietrznej budynku, jednocześnie zachowując odpowiednią sztywność układów kratowych. Na przytaczanych wyżej przykładach zaobserwować można, iż budynki posiadają wyraźnie węższe dwie przeciwległe strony, jednocześnie zachowując prostą, zwartą formę, zapewniającą sztywność konstrukcji. Z tych właśnie względów konstrukcja (i estetyka) zrealizowanych do tej pory wysokich i wysokościowych obiektów w technologii drewna klejonego oparta jest na prostopadłościennej ramie oraz wykorzystaniu dużych jednolitych, prefabrykowanych drewnianych paneli, służących jako stropy, ściany i elewacje budynku.

Bernhard Gafner, inżynier konstrukcyjny z firmy Fast + Epp, uważa iż obiekty wykonane z elementów prefabrykowanych z drewna klejonego wykonywane są conajmniej o $25 \%$ szybciej niż w przypadku innych technologi, jednocześnie zmniejszając aż o 90\% ruch na budowie, związany z dostawami i przygotowaniem materiału. Ze względu na uproszczony sposób montażu, stanowią one również większe bezpieczeństwo dla załóg budowlanych. ${ }^{13}$ Klasyfikacją wysokich i wysokościowych budynków zajmuje się organizacja Council on Tall Buildings and Urban Habitat, dzieląc budynki według typu konstrukcji i zastosowanego materiału. Typologia przyjęta przez organizację przyjmuje następujące kategorie: budynki jednomateriałowe, budynki kompozytowe i układy konstrukcyjne mieszane. Znaczna część z realizowanych wysokościowych budynków drewnianych, kwalifikowana jest jako kompozytowe, ze względu na wykorzystanie cięgien stalowych do usztywnienia konstrukcji, bądź mieszane, gdzie wykorzystano betonowe rdzenie jako element konstrukcyjny. Niemniej, obiekty gdzie 85\% konstrukcji wykonana jest z drewna, traktowane są jako drewniane. Podstawowymi typami są konstrukcje wykonane w technologii szkieletu drewnianego (w przypadku budynków niższych), oraz słupowo ryglowej i prefabrykowanych, wielkowymiarowych elementów drewnianych ${ }^{14}$ (w przypadku budynków wysokich i wysokościowych).
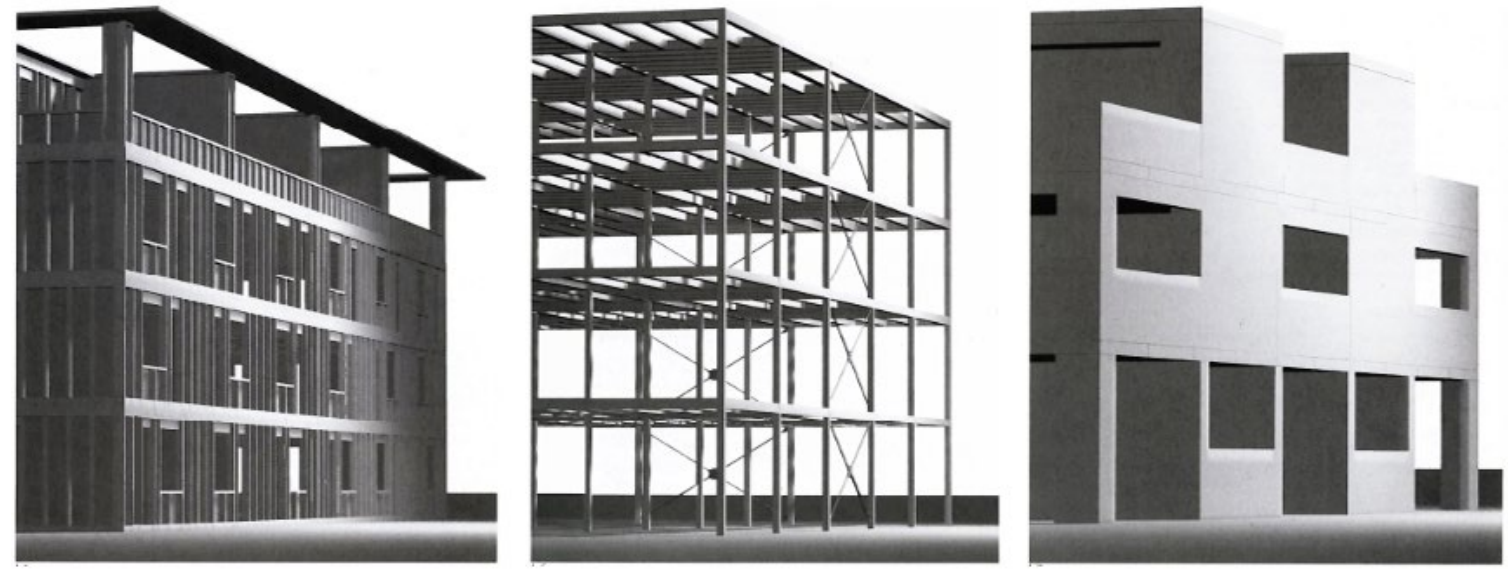

Ryc. 6. Typy konstrukcji z drewna klejonego: szkielet drewniany, słupowo - ryglowa i prefabrykowanych, wielkowymiarowych elementów drewnianych

Źródło: Opracowanie graficzne firmy Fast + Epp, za: https://www.thinkwood.com/education, stan na dzień 25.03.2020.

12 Foster R., Ramage M, Rethinking CTBUH Height Criteria In the Context of Tall Timber, CTBUH Journal, 2017 Issue IV.

13 Za: Mass Timber in North America. Expanding the possibilities of wood building design, materiały edukacyjne, American Wood Council, dostępne na: https://www.thinkwood.com/education, stan na dzień 25.03.2020. 


\section{Rozwiązania pro-ekologiczne}

W intensywnie rozwijającym się świecie istotną kwestią jest dbanie o środowisko naturalne i zrównoważone gospodarowanie zasobami planety. Branża budowlana ma również znaczny wkład w wykorzystanie surowców naturalnych oraz produkcję zanieczyszczeń, wpływających negatywnie m.in. na jakość powietrza i wzrost efektu cieplarnianego. Produkcja betonu wykorzystywanego we współczesnym budownictwie odpowiedzialna jest za 5\% światowej emisji $\mathrm{CO}_{2}$, przyczyniając się wyraźnie do zwiększenia efektu cieplarnianego. Szacuje się że jego transport od miejsca produkcji na place budowlane produkuje pięciokrotnie więcej dwutlenku węgla niż cały ruch lotniczy ${ }^{15}$. Jak twierdzi Sylvie Lemmet, dyrektor w dziale Technologii, Przemysłu i Ekonomii w UNEP ${ }^{16}$ : "W ciagu czterdziestu lat musimy zmniejszyć emisje gazów cieplarnianych o co najmniej 50\%, aby uniknąć najgorszych scenariuszy zmian klimatu"177. Użycie drewna w budownictwie może w sposób znaczny przyczynić się do pozytywnych zmian środowiskowych, jednocześnie polepszając jakość i estetykę przestrzeni miejskich. Całkowite zastąpienie betonu i stali materiałami pochodzenia naturalnego, wg szacunków mogłoby wpłynąć na emisję $\mathrm{CO}_{2}$ zmniejszając ją o $15-20 \%^{18}$. Drewno użyte do budowy budynków, z biegiem czasu musi ulec wymianie, bądź konserwacji. Usunięte elementy budynku mogą zostać wykorzystane ponownie, jako budulec w mniej wymagających strukturach, bądź jako materiał opałowy, tworząc w ten sposób obieg w użyciu materiału. Aby zapewnić stały dostęp do naturalnego materiału budulcowego, jakim jest drewno, należy najpierw zadbać o właściwą gospodarkę leśną. Popularyzacja komercyjnej plantacji drzew na cele budowlane może dodatkowo pozytywnie wpłynąć na jakość środowiska, zapewniając czyste powietrze oraz miejsce do życia dla zwierząt.

Rola lasów jako naturalnych filtrów powietrza, jak i również odnawialnego magazynu surowcowego zdaje się mieć coraz większe znaczenie $w$ dynamicznie rozwijającym się świecie. ${ }^{19}$ Ważnym aspektem jest również fakt pozytywnego wpływu wnętrz wykonanych w drewnie na samopoczucie i zadowolenie użytkowników. Przeprowadzone w Kanadzie badania dowodzą iż drewno jako materiał wykończeniowy odbierane jest jako sielskie, przyjemne i uspokajające ${ }^{20}$, pomagając jednocześnie w zmniejszeniu poczucia zmęczenia i przygnębienia wśród osób stale przebywających wewnątrz takiego obiektu ${ }^{21}$.

\section{Aspekty prawne. Bezpieczeństwo pożarowe}

Główną przeszkodę w realizacji wysokich i wysokościowych budynków z drewna klejonego, zarówno w Polsce jak i w innych krajach stanowią przepisy budowlane, które ze względów bezpieczeństwa ograniczają rozwój budownictwa z wykorzystaniem wspomnianych technologii. Wynika to w dużej mierze z faktu, iż drewno klejone stanowi stosunkowo nowy materiał, który nie jest obecnie odpowiednio zbadany, w celu uzyskania niezbędnych certyfikacji, pozwalających na zmianę przepisów prawnych. Wraz z rozwojem technologii i prowadzonymi licznymi badaniami nad właściwościami drewna, sytuacja prawna w wielu krajach stopniowo ulega zmianie. W 2010 w Japonii uchwalono ustawę o promocji wykorzystania drewna w budynkach użyteczności publicznej, zachęcając do realizacji obiektów w technologii drewna klejonego, gdzie do tej pory stosowano wyłącznie materiały takie jak ceramika, beton czy stal. Z kolei w 2011 dopuszczono w Finlandii budowę drewnianych budynków do 8 kondygnacji nadziemnych (czyli zasięgu drabiny wozu strażackiego), co wpłynęło na popularyzację omawianej technologii. Do 2016 roku przeprowadzono w Kanadzie szereg badań związanych

15 Rosenfield K., Michael Green presents: 'The Case for Tall Wood Buildings', Arch Daily, 2012, https://www.archdaily.com/220779/michaelgreen-presents-the-case-for-tall-wood-buildings, stan na dzień 27.03.2020.

16 Program Narodów Zjednoczonych ds. Środowiska na 2009.

17 Sherifi E., Fager-Thompson M., Mass timber in tall buildings design A Major Qualifying Project Report, Faculty of Worcester Polytehnic Institute's Civil and Enviromental Engineering Department, 2017

18 Cornwall W., Would you live in a wooden skyscraper, Science, 2016, https://www.sciencemag.org/news/2016/09/would-you-live-woodenskyscraper stan na dzień 27.03.2020.

19 Za: Malo K.A., Abrahamsen R.B. i Bjertnæs, M.A., Some structural design issues of the 14-storey timber framed building "Treet" in Norway, European Journal of Wood and Wood Products, nr 74(3), 2016.

20 Rice J., Kozak R., Meitner M., Cohen D., Appearance wood products and psychological well-being, Wood and Fiber Science, nr 4, 2006.

21 Sakuragawa S., Miyazaki Y., Kaneko T., Influence of wood wall panels on physiological and psychological responses, Journal of Wood Science, 2005. 
z właściwościami mechanicznymi drewna klejonego, doprowadzając do wdrożenia odpowiednich przepisów budowlanych określających właściwości elementów drewnianych w procesach ścinania i dopuszczalnych ugięć. ${ }^{22}$

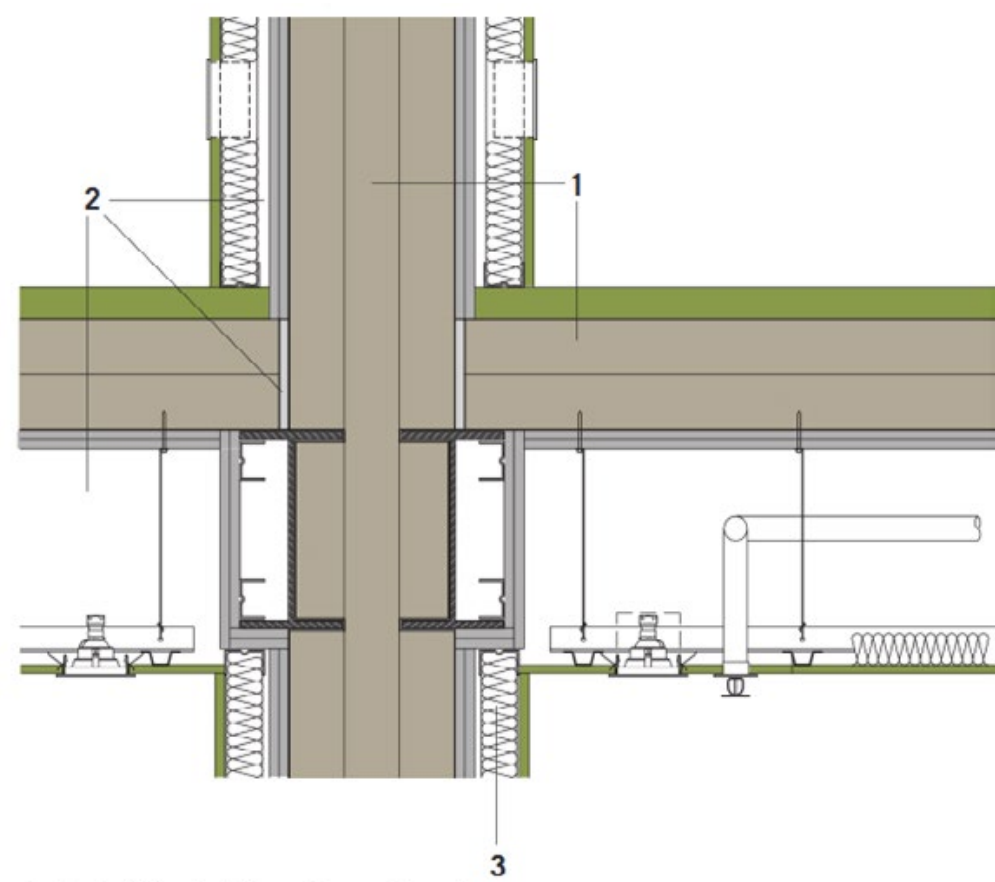

1. Grubość i gęstość drewnianego elementu

2. Przerwy technologiczne nalączęniach elementu (dylatacje)

3. Pokrycie materialem absorbującym dźwięk.
Ryc. 7. Metody poprawy właściwości akustycznych budynków drewnianych. Za: Green M.,C., The case for tall wood buildings - How mass timber offers a safe, economical, and environmental friendly alternative for tall building structures, Equilibrium Consulting, 2012. Ilustracja na licencji Creative Commons.

Wiele organizacji i firm zajmujących się rozwojem drewnianych technologii budowlanych na przestrzeni ostatnich lat przeprowadziło liczne testy, badające odporność pożarową elementów z drewna klejonego. W federalnym laboratorium badawczym $\mathrm{ATF}^{23}$ w USA przeprowadzono testy prefabrykowanych elementów drewnianych w kierunku odporności pożarowej. Pięciowarstwowy panel poddano próbie ognia, trwającej 3 godziny i 6 minut $w$ temperaturze ok $982^{\circ} \mathrm{C}$. Badania potwierdziły że elementy z drewna klejonego nie tylko spełniają założone normy odpornościowe, ale i wyraźnie je przewyższają. Zaobserwowano iż zewnętrzne włókna, zabezpieczone klejem ulegają zwęgleniu, izolując wewnętrzną część elementu od płomienia i zapewniając jej odpowiednią wytrzymałość. Ze względu na zwartą homogeniczną strukturę, oraz zastosowanie warstwy kleju jako laminat, panele warstwowe mogą uzyskać klasę odporności ogniowej El30, zapewniającą integralność elementu przez min. 30 minut w czasie trwania pożaru. Wytrzymałość elementu jest oczywiście zależna od ilości zastosowanych warstw drewna. We wspomnianym wyżej budynku Stadthaus w Londynie, zastosowano pięciowarstwowy panel, zapewniający odporność ogniową przez 60 minut. Istnieją również inne metody zabezpieczenia konstrukcji drewnianej przed działaniem pożaru, dodatkowo zwiększające jej odporność. Jedną z metod jest hermetyzacja. Polega ona na obłożeniu drewnianych elementów podwójną warstwą płyt gipsowych, zmniejszając narażenie konstrukcji na płomienie. Metoda ta wykazała iż elementy z drewna klejonego, odizolowane od źródła ognia, są w stanie zapewnić nośność konstrukcji dłużej niż stal, gdyż nie mają tendencji do uplastyczniania się pod wpływem wysokich temperatur. ${ }^{24}$ Warto również zwrócić uwagę, że wiele przepisów przeciwpożarowych, ograniczających wysokość budynków wynika z zasięgu drabiny wozu strażackiego. Jest to wytyczna nieadekwatna 
do czasów współczesnych, gdzie w wielu budynkach na szeroką skalę stosuje się różne instalacje przeciwpożarowe (tryskacze, systemy oddymiające itp.), które są w stanie szybciej i skuteczniej zdusić pożar niż wóz strażacki. Nowoczesne i bardziej niezawodne systemy zraszania, do zastosowania w budownictwie drewnianym są opracowywane w Austrii, gdzie drewniane budowle, przed odbiorem muszą przejść rygorystyczne kontrole ${ }^{25}$.

Dodatkowym problemem w budynkach z drewna klejonego są właściwości akustyczne. Panel drewniany, szczególnie w przypadku sztywnego łączenia elementów, posiada znacznie wyższy współczynnik przenikania dźwięku, niż tradycyjnie realizowane konstrukcje budowlane. W celu zapewnienia odpowiedniej izolacyjności akustycznej, elementy drewniane muszą zostać pokryte warstwą materiału izolacyjnego. Można również stosować technologie powszechnie wykorzystywane, jak "podłogi pływające”, bądź sufity podwieszane, tworzące pustkę, pomagającą zmniejszać przenikanie dźwięku.

\section{Kierunki rozwoju - podsumowanie}

Projektowanie wysokich budynków w technologii drewna klejonego zdaje się stopniowo zyskiwać na popularności. Biura architektoniczne coraz częściej prezentują odważne i kreatywne pomysły. Jak twierdzi Simon Smith z pracowni Smith and Wallwork: "jest to jedynie kwestia czasu, kiedy powstanie pierwszy drewniany drapacz chmur $^{\prime \prime 2}$. Za przykład może posłużyć projekt budynku Barbican w Londynie. Ten 300 metrowy, 80-cio kondygnacyjny wieżowiec, zaprojektowany przez pracownię PLP Architecture, pokazuje iż drewno daje ogromne możliwości w kształtowaniu nowoczesnej, ekologicznej i estetycznej przestrzeni miejskiej. Jeden z projektantów pracowni, Kevin Flanagan, twierdzi że powszechne wprowadzenie do użycia technologii drewna klejonego może zupełnie zmienić sposób, w jaki budowane są miasta, tworząc przyjemniejszą i kreatywną przestrzeń urbanistyczną, sprzyjającą kontaktom społecznym ${ }^{27}$.

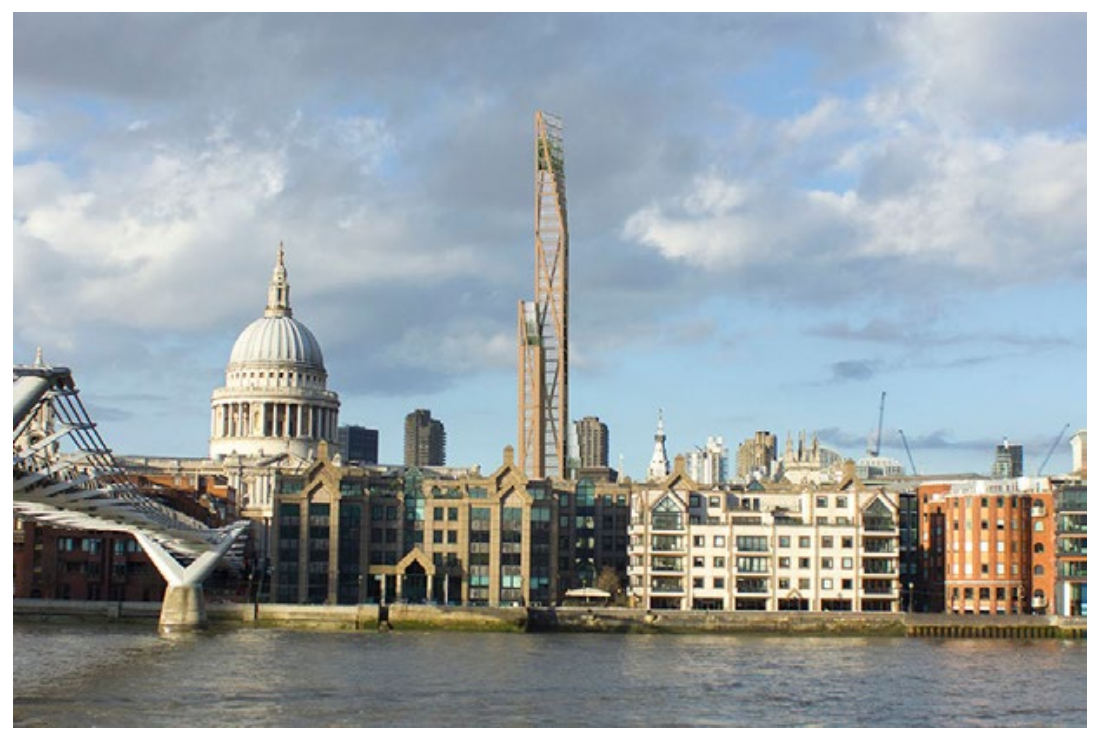

Ryc. 8. Wizualizacja koncepcyjna drewnianego wieżowca Barbican w Londynie

Źródło: http://www.plparchitecture.com/oakwood-timber-tower. html. Stan na dzień 29.03.2020

Inne biura architektoniczne zdają się również wpisywać w tendencję rozwoju wspomnianych technologii, oferując odważne i kreatywne rozwiązania projektowe, wychodzące znacznie poza proste, prostopadłościenne formy zrealizowane do tej pory. Za przykład mogą posłużyć m.in. koncepcje 18-kondygnacyjnego budynku "Hyperion" pracowni Jean Paula Viguier w Bordeaux, czy 80-cio metrowego Barenthus Zaprojektowanego przez

25 French, M., Vienna plans world's tallest wooden skyscraper. The Guardian, 2015. Źródło: http://www.theguardian.com/cities/2015/mar/01/ vienna-plans-worlds-tallest-wooden-skyscraper. Stan na dzień 28.03.2020.

26 Mairs J., PLP Architecture proposes London's first wooden skyscraper at the Barbican, https://www.dezeen.com, 2016. Stan an dzień 29.03.2020. 
Reiulf Ramstad Arkitekter AS. Podobnych przykładów można mnożyć wiele, co wskazuje wyraźnie na kierunek przyjęty w rozwoju nowoczesnej architektury.

W obecnych czasach zrozumienie potrzeb zrównoważonego rozwoju i efektywne wykorzystanie zasobów naturalnych może być kluczowe dla dalszego kształtu nowoczesnych miast. Rozwój technologii budowlanych otwiera nowe możliwości, pozwalające tworzyć wysokie budynki w sposób wydajniejszy i bardziej przyjazny środowisku. Drewno jest czymś więcej niż jedynie materiałem budowlanym. Jest surowcem wykorzystywanym przez człowieka od początków cywilizacji i zakorzenionym głęboko w tradycjach lokalnych. Przebywanie w drewnianych budynkach wpływa pozytywnie na samopoczucie użytkowników, a odpowiednia gospodarka leśna jest w stanie zarówno dostarczyć odpowiedni surowic budowlany, jak i również wpłynąć na poprawę naturalnego środowiska wokół miast. Szerokie zainteresowanie tematem dużych pracowni projektowych może sugerować utrzymanie trendu rozwojowego wspomnianych technologii w najbliższych latach.

\section{Bibliografia}

[1] Abrahamsen R.B., Malo K.A, Structural design and assembly of Treet - a 14-storey timber residental building in Norway, [w:] materiały pokonferencyjne World Conference on Timber Engineering, 10.08.2014 r.

[2] Cornwall W., Would you live in a wooden skyscraper, Science, 2016.

[3] Crockett L., World's tallest timber tower tops out in Vancouver.

[4] Foster R., Ramage M, Rethinking CTBUH Height Criteria In the Context of Tall Timber, CTBUH Journal, 2017 Issue IV.

[5] French, M., Vienna plans world's tallest wooden skyscraper. The Guardian, 2015.

[6] Green M.C., The case for tall wood buildings - How mass timber offers a safe, economical, and environmental friendly alternative for tall building structures, Equilibrium Consulting, 2012.

[7] Mairs J., PLP Architecture proposes London's first wooden skyscraper at the Barbican.

[8] Malo K.A., Abrahamsen R.B. i Bjertnæs, M.A., Some structural design issues of the 14-storey timber framed building "Treet" in Norway, European Journal of Wood and Wood Products, nr. 74(3), 2016.

[9] Mass Timber in North America. Expanding the possibilities of wood building design, materiały edukacyjne, American Wood Council.

[10] Mohammad, M., Gagnon, S., Douglas, B., Podesto, L., Introduction to Cross Laminated Timber, 2017.

[11] Rice J., Kozak R., Meitner M., Cohen D., Appearance wood products and psychological well-being, Wood and Fiber Science, $\mathrm{nr}$ 4, 2006.

[12] Rosenfield K., Michael Green presents: 'The Case for Tall Wood Buildings', Arch Daily, 2012.

[13] Sakuragawa S., Miyazaki Y., Kaneko T., Influence of wood wall panels on physiological and psychological responses, Journal of Wood Science, 2005.

[14] Sherifi E, Fager-Thompson M., Mass timber in tall buildings design A Major Qualifying Project Report, Faculty of Worcester Polytehnic Institute's Civil and Enviromental Engineering Department, 2017.

[15] Steinhardt N., Liao: An Architectural Tradition in the Making, [w:] Artibus Asiae, vol. 54, nr. 1/2, 1994.

\section{Źródła internetowe}

[1] https://www.archdaily.com/220779/michael-green-presents-the-case-for-tall-wood-buildings

[2] https://www.archdaily.com/794170/worlds-tallest-timber-tower-tops-out-in-vancouver

[3] https://www.dezeen.com/2016/04/08/plp-architecture-cambridge-university-london-first-wooden-skyscraper-barbican/

[4] https://www.sciencemag.org/news/2016/09/would-you-live-wooden-skyscraper

[5] http://www.theguardian.com/cities/2015/mar/01/vienna-plans-worlds-tallest-wooden-skyscraper

[6] https://www.thinkwood.com/education 


\title{
Use of laminated timber in the construction of high-rise buildings, on the example of implementations from western countries
}

\begin{abstract}
Abstarct: The architecture of modern, $20^{\text {th }}$ and early $21^{\text {st }}$ century high-rise buildings is primarily associated with materials such as steel, glass and concrete. With the advancement and popularity of laminated timber construction in western countries the use of wood as a structural component in high rise buildings brings many economic, technological and logistical benefits. Laminated timber is more flexible, lighter and often more durable than typically used materials in construction. Thanks to cross lamination technology, buildings are able to obtain significant heights while maintaining appropriate structural requirements. This material turns out to be easier to transport, and with proper prefabrication, will also speed up the construction processes at a reduced cost. Timber is an eco-friendly material, that with properly managed forests ensures a sustainable, renewable construction supply. This minimizes the cost to the environment by reducing $\mathrm{CO}_{2}$ emissions. The main obstacle to the implementation of this technology at a larger scale are numerous legal restrictions regarding strength and fire resistance. The research and implementation examples cited in the article below show that laminated wood is able to maintain appropriate structural requirements, ensuring the durability and safety of its occupants.
\end{abstract}

Keywords: architecture, high-rise buildings, glued laminated timber, fire safety 